\title{
METODE PENGEMBANGAN KETERAMPILAN BERCERITA YANG BERKARAKTER UNTUK PENDIDIKAN ANAK USIA DINI
}

\author{
Hj. Etty Rohayati
}

\begin{abstract}
Abstrak
Sebagaimana diketahui bahwa setiap kegiatan pembelajaran yang akan dilaksanakan tidak terlepas dari metode dan strategi pembelajaran. Metode itu suatu prosedur pelaksanaan kegiatan dalam pengembangan atau pembelajaran. Dalam kaitannya dengan pendidikan anak usia dini, salah satu metode yang dapat digunakan adalah metode bercerita. Bercerita adalah suatu kegiatan yang dilakukan seseorang secara lisan kepada orang lain dengan alat atau tanpa alat, umumnya yang disampaikan penutur dalam bentuk pesan, informasi. Begitu juga cerita anak-anak disampaikan pada sebuah dongeng untuk didengarkan dengan rasa menyenangkan. Dalam menyampaikan cerita dongeng seorang guru harus mampu menyajikannya secara menarik dan ekspresi yang meyakinkan. Sejalan dengan hal tersebut, guru PAUD harus mampu menguasai metode bercerita secara mendalam agar mampu melaksanakan pembelajaran dengan menggunakan metode mendongeng secara tepat guna, tetap sasaran, dan tepat tujuan.
\end{abstract}

\section{Kata Kunci: Pengembangan Bercerita, Karakter, PAUD.}

\section{A. Pendahuluan}

Bercerita adalah suatu kegiatan yang dilakukan seseorang secara lisan kepada orang lain dengan alat atau tanpa alat, umumnya yang disampaikan penutur dalam bentuk pesan, informasi begitu juga cerita anak- anak disampaikan pada sebuah dongeng untuk didengarkan dengan rasa menyenangkan, oleh karena itu orang menyampaikan cerita dongeng secara menarik dan ekspresi yang meyakinkan. Anak-anak usia empat tahun sampai enam tahun umumnya senang mendengarkan cerita sederhana sesuai dengan perkembangan usianya. Juga anak seusia itu mempunyai potensi untuk menyerap segala hal lebih cepat, sehingga lebih mudah membentuk dan mengarahkan dirinya.

Pada masa inilah guru atau orang tua memberikan suatu cerita dengan pendidikan berkarakter di antaranya: cinta Tuhan dengan segenap ciptaan-Nya. kemandirian dan tanggung jawab, kejujuran atau amanah, hormat dan santun, dermawan suka tolong menolong, gotong royong, percaya diri, pekerja cerdas, kepemimpinan dan keadilan, baik hati dan rendah diri, toleransi, kedamaian dan persatuan. Hal ini harus dilakukan sesuai dengan kurikulum ke-PAUD-an (Depdiknas 1996:1) yang menyatakan” PAUD seharusnya mampu meletakkan dasar ke arah perkembangan sikap, pengetahuan, keterampilan dan daya cipta yang diperlukan oleh anak didik dalam menyesuaikan diri dengan lingkungannya dan untuk pertumbuhan serta perkembangan selanjutnya.

\section{B. Konsep Dasar Metode Bercerita}

Metode bercerita adalah cara penyampaian atau penyajian materi pembelajaran secara lisan dalam bentuk cerita. Metode bercerita dilaksanakan 
dalam upaya memperkenalkan, memberikan keterangan, atau penjelasan tentang hal baru dalam rangka menyampaikan pembelajaran yang dapat mengembangkan berbagai kompetensi dasar anak usia dini. Dhieni N. (2008: 6.7) "Metode bercerita untuk anak-anak sepadam dengan metode ceramah untuk orang dewasa."

Tujuan Bercerita Untuk anak usia 4-6 tahun agar anak mampu menyimak dengan sesama terhadap apa yang disampaikan orang lain, anak bertanya, apabila tidak memahaminya. Anak dapat menjawab pertanyaan, anak dapat menceritakan kembali dengan ekspresinya terhadap apa yang disimaknya atau didengarnya. Dengan demikian adanya keterpaduan dengan keterampilan bahasa yang lainnya. Menurut Tampubolon (1991:10) "Bahasa berpengaruh besar pada perkembangan pikiran anak".

Manfaat Metode Bercerita antara lain sebagai berikut.

1. Melatih daya serap atau daya tangkap

2. Melatih daya pikir

3. Melatih daya konsentrasi

4. Mengembangkan daya imajinasi anak

5. Menciptakan situasi yang menggembirakan serta mengembangkan suasana hubungan yang akrab sesuai dengan terhadap perkembangannya.

6. Membantu perkembangan bahas anak dalam berkomunikasi secara efektif dan efisien sehingga proses percakapan menjadi komunikatif.

Isi cerita untuk pendidikan anak usia dini biasanya mengandung nilai moral yang mengarah pada pengembangan emosi, sosial, spiritual anak dan tidak terlepas dari aspek pendidikan. Dilihat dari proses pelaksanaan/ penampilan dalam pengembangan bercerita bisa memakai alat peraga, dan tanpa alat peraga. Bercerita tanpa alat peraga pada prosesnya yang dilakukan guru hanya mengandalkan suara, mimik atau ekspresi dan gerak anggota tubuh guru.

Metode bercerita memiliki kelebihan antara lain sebagai berikut.

1. Anak dilatih konsentrasi

2. Anak belajar menjadi pendengar yang baik

3. Anak berfantasi terhadap obyek yang tidak nyata

4. Anak belajar menyimak apa yang diperagakan oleh guru, dan

5. Anak belajar mengingat apa yang diceritakan guru.

Metode bercerita memiliki kelemahan antara lain sebagai berikut.

1. Guru malas untuk berekspresi

2. Tidak semua anak memiliki potensi atau kemampuan yang sama.

3. Anak pasif ketika guru bercerita

4. Anak tidak mampu menyerap fantasi ekspresi dan gerakan guru ketika bercerita

5. Anak kurang memahami alur cerita ketika guru bercerita ada kata-kata yang kurang dimengerti (Dhieni, 2008;6.19)

\section{Pengertian Bercerita dengan Media/Alat Peraga}

Kegiatan bercerita dengan menggunakan media atau alat pendukung isi cerita yang ditampilkan, alat peraga atau media hendaknya aman, menarik, dan sesuai dengan tahap perkembangan anak. Russeli (1993)" media merupakan saluran komunikasi” contohnya film, televisi, diagram, komputer, instruktur dll., 
dan media tersebut membawa pesan dalam rangka mencapai tujuan pembelajaran. Media atau alat peraga ada yang asli atau alami dari lingkungan sekitar dan dapat juga dari benda tiruan atau fantasi.

Tujuan Bercerita dengan Alat Peraga adalah bahwa dengan alat peraga secara tepat anak dapat menanggapi isi cerita dan membantu imajinasi anak memahami isi cerita yang disampaikan guru. Fungsi Bercerita dengan Alat Peraga bagi guru akan terasa lebih ringan dalam menyampaikan cerita, bagi anak akan lebih menarik. Bentuk-bentuk bercerita dengan alat peraga terbagi dua bagian yaitu bercerita dengan alat peraga langsung dan bercerita dengan alat peraga tak langsung atau benda tiruan. Alat peraga langsung ; isi cerita sesuai dengan tahap perkembangan anak dan media yang digunakan, menggunakan gaya bahasa anak, alat peraga yang digunakan tidak membahayakan guru maupun anak didik, dan alat peraga atau media yang digunakan dapat tersimpan pada suatu tempat atau dapat dipegang langsung oleh guru atau siswa.

Bercerita dengan alat peraga tak langsung atau tiruan. Misalnya tiruan dari; binatang, buah, sayur, dsb. Yang terbuat dari berbagai bahan misalnya kayu, plastik, fiber, denda tersebut hendaknya bentuk dan warnanya sesuai dengan aslinya. Kegiatan Bercerita dengan Alat Peraga Tak Langsung, terdiri dari:

1. Bercerita dengan gambar

2. Bercerita dengan kartu

3. Bercerita dengan papan panel

4. Bercerita dengan buku cerita

5. Bercerita dengan boneka

6. Bercerita dengan menggambar.

\section{Pengembangan Metode Bercerita untuk Pembinaan Karakter Anak Usia Dini}

Sebagaimana kita ketahui bahwa setiap kegiatan pembelajaran ataupun pengembangan yang akan dilaksanakan tidak terlepas dari metode dan strategi pembelajaran. maksudnya Metode itu suatu cara pelaksanaan kegiatan dalam pengembangan atau pembelajaran. Menurut Zuchdi (1997:30) "metode pembelajaran bahasa ialah rencana pembelajaran bahasa, yang mencakup pemilihan, penentuan, dan penyusunan secara sistematis bahan yang akan diajarkan serta kemungkinan pengadaan remedi pengembangannya.” Sedangkan yang dimaksud strategi adalah langkah-langkah pelaksanaan kegiatan pada pengembangan atau pembelajaran bahasa Montolalu. (2009: 9) mengungkapkan strategi yang digunakan dalam kondisi pembelajaran di Taman kanak-kanak adalah "keterampilan dalam mengatur pembelajaran dengan menggunakan kiatkiat yang sesuai agar mencapai hasil maksimal” .

Karakter kegiatan yang berhubungan dengan tingkah laku kepribadian seseorang di masyarakatnya. Dennis Coon dalam bukunya “ introduction of Psychologi Exploration and Aplication" mendefinisikan "karakter sebagai suatu penilaian subyektif terhadap kepribadian seseorang yang berkaitan dengan atribut kepribadian yang dapat atau tidak dapat diterima oleh masyarakat”.

$$
\text { Menurut Brazilton (ahli perkembangan dan perilaku anak) }
$$

mengungkapkan bahwa "pengalaman anak pada bulan dan tahun pertama 
kehidupannya sangat menentukan. Apakah anak akan mampu menghadapi tantangan dalam kehidupannya? Dan apakah ia akan menunjukkan semangat tinggi untuk belajar dan berhasil dalam pekerjaannya?” kesimpulannya kita harus memanfaatkan masa emas dalam kehidupan anak untuk memberikan pendidikan karakter yang baik di masyarakatnya.

..... Karakter yang perlu ditumbuhkan dan dibentuk dalam diri anak di antaranya;

1. Cinta Tuhan dan segenap ciptaan-Nya.

2. Kemandirian dan tanggung jawab.

3. Kejujuran atau amanah, diplomatis.

4. Hormat dan santun.

5. Dermawan, suka tolong-menolong dan gotong royong.

6. Percaya diri dan pekerja cerdas.

7. Kepemimpinan dan keadilan.

8. Baik dan rendah hati

9. Toleransi, kedamaian dan kesatuan.

Membangun karakter melalui pendidikan anak usia dini dapat dilakukan melalui pendidikan formal, nonformal, dan informal. Upaya yang dilakukan oleh guru atau orang tua dalam membangun karakter anak usia dini

1. Memperlakukan anak sesuai dengan karakteristik anak

2. Memenuhi kebutuhan dasar anak antara lain, kebutuhan kasih sayang, pemberian makanan yang bergizi.

3. Pola pendidikan guru dan orang tua yang dilaksanakan baik di rumah dan di sekolah saling berkaitan.

4. Berikan dukungan dan penghargaan ketika anak menampilkan tingkah laku yang terpuji.

5. Berikan fasilitas lingkungan yang sesuai dengan usia perkembangan.

6. Bersikap tegas, konsisten dan bertanggung jawab.

Dennis Coon dalam bukunya Introduction of Psychologi Exploration and Aplication mendivisikan "karakter sebagai suatu penilaian subyektif terhadap kepribadian seseorang yang berkaitan dengan atribut kepribadian dan dapat atau tidak dapat diterima oleh masyarakat”. Karakter adalah jawaban mutlak untuk menciptakan kehidupan yang lebih baik di dalam masyarakat.

Contoh Strategi Satuan Kegiatan Harian (SKH) pada Metode Bercerita yang berkarakter untuk AUD yakni dengan metode bercerita dengan satu gambar.

1. Ketentuan Kegiatan Bercerita Satu Gambar

a. Judul cerita singkat dan menarik bagi anak didik

b. Cerita singkat dan sarat dengan nilai-nilai kehidupan yang ada di lingkungan anak.

c. Menggunakan gaya bahasa anak.

d. Gambar dibuat dalam ukuran satu karton 60 X60 cm.

e. Gambar menggambarkan tokoh yang sedang bereaksi dengan menarik.

f. Gambar dibuat sesuai dengan tahap perkembangan anak.

g. Gambar diberi warna yang menarik dan tidak mengaburkan imajinasi anak.

h. isi cerita ditulis pada bagian belakang gambar.

2. Langkah-langkah pelaksanaan 
a. Anak mengatur posisi duduknya.

b. Anak memperhatikan guru menyiapkan alat peraga.

c. Anak termotivasi untuk mendengarkan cerita.

d. Anak diberi kesempatan untuk memberi judul cerita.

e. Guru melengkapi judul cerita dari anak

f. Anak mendengarkan cerita sambil memperhatikan gambar yang diperlihatkan

g. Setelah selesai bercerita anak memberikan kesimpulan isi cerita

h. Guru melengkapi kesimpulan tentang isi cerita dari anak.

3. Evaluasi.

Setelah selesai bercerita guru bertanya tentang isi cerita, tokoh dalam cerita, dan memberi kesempatan pada satu atau dua anak untuk menceritakan kembali.

\section{E. Penutup}

Membangun karakter melalui pendidikan anak usia dini dapat dilakukan melalui pendidikan formal, nonformal, dan informal. Dalam kaitannya dengan pembelajaran di PAUD, pengembangan karakter dapat dilakukan melalui penggunaan metode pembelajaran yang tepat. Salah satu metode pembelajaran tersebut adalah metode bercerita.

Melalui metode bercerita, guru dapat memodifikasi pengembangan karakter anak baik melalui penggunaan alat peraga maupun tanpa alat peraga. Bercerita dengan alat peraga sendiri diharapkan lebih mampu menarik minat anak agar terfokus pada cerita yang disampaikan guru sehingga karakter yang terkandung dalam cerita akan mampu dipahami anak. Selanjutnya, diharapkan anak mampu berkarakter lebih baik dalam setiap kehidupannya.

\section{DAFTAR PUSTAKA}

Depdiknas 2010. Garis -Garis Besar Program Kegiatan Belajar PAUD. Jakarta: Depdiknas.

Dhieni, N. et.al 2008. Metode Pengembangan Bahasa. Jakarta: Universitas Terbuka.

Montolalu, B.E.F. et.al 2009. Bermain dan Permainan Anak. Jakarta: Universitas Terbuka.

Russeli S. Heinich M. 1993. Intructional Media and Technologies for Learning. New Jersey: Prestice Hall Engelwood.

Zuchdi,Darmiyati. 1997. Pendidikan Bahasa dan Sastra Indonesia di Kelas Rendah. Bandung: UPI Pers.

\section{BIODATA PENULIS}

Etty Rohayati adalah dosen pada Universitas Pendidikan Indonesia dpk. UPI Kampus Cibiru Bandung. 